\title{
Percutaneous Ethanol Ablation for Management of Cystic Thyroid Nodules: A Case Report
}

\author{
Kristanto Yuli Yarso ${ }^{1}$, Monica Bellynda ${ }^{2}$ \\ ${ }^{1}$ Division of Surgical Oncology, Department of Surgery, Dr. Moewardi General Hospital, Surakarta, Indonesia \\ ${ }^{2}$ Resident of Surgery, Faculty of Medicine, Sebelas Maret University, Dr. Moewardi General Hospital, Surakarta, Indonesia
}

\section{ARTICLE INFO}

Received : 10 May 2020

Reviewed : 10 June 2020

Accepted : 04 August 2020

Keywords:

thyroid nodules, thyroid cyst,

percutaneous ethanol ablation

*Corresponding author:

Monica Bellynda

Resident of Surgery, Faculty of Medicine,

Sebelas Maret University,

Dr. Moewardi General Hospital,

Surakarta, Indonesia

email: monicabellynda@hotmail.com

\section{A BSTRACT}

Introduction: Percutaneous Ethanol Ablation (PEA) has been recommended as the first-line treatment option for symptomatic benign cystic or predominantly cystic thyroid nodules, and it has been shown to be more effective and safer than other techniques in previous studies. Here, we present a case of a 44-year-old man with thyroid nodules who underwent PEA.

Case Presentation: We report the case of a 44-year-old man with a painless mass that is getting bigger on his right neck. The physical examination measured $3.0 \times 3.0 \times 3.0 \mathrm{~cm}$, mobile on swallowing, no pain on palpation. Thyroid function tests show a euthyroid state (TSH $2.4 \mathrm{mIU} / \mathrm{L}$, FT4 $1.2 \mathrm{ng} / \mathrm{dL}$ ). The ultrasound examination in January 2020 showed a colloid cyst on the right thyroid, measured $3.03 \times 2.82 \times 3.56 \mathrm{~cm}$ (TIRADS 1). Cytological examination showed the results of non-infectious cystic fluid. The patient underwent US-guided PEA using $7 \mathrm{ml}$ of ethanol by the moving-shot technique. The procedure was well tolerated by the patient and no adverse events were noted. A week after the procedure, there was a visible and progressive reduction of the nodule with no complaint from the patient. A month after the procedure, the patient came back with no recurrences, complaints, or other complications.

Conclusions: PEA for thyroid lesions is an effective and safe method. PEA should be the first option for the treatment of pure cystic and predominantly cystic nodules. PEA is a safe procedure that is easy to repeat and to be performed on an outpatient basis.

\section{INTRODUCTION}

Thyroid nodule is a common disease that can either be palpated or made out during imaging like ultrasonography (USG). The prevalence of clinically palpable thyroid nodule was about $4-7 \%$ and increased to $20-76 \%$ when USG was used for detection. However, most of these nodules ( $>90 \%$ ) are benign and relatively unchanged over time; generally, only observations and guarantees are needed [1-3]. Thyroid surgery is the most common management performed with minimal complications and mortality. Thyroid surgery is the firstline treatment for recurrent thyroid cysts producing aesthetic complaints or compressive symptoms. However, there are several obstacles including the incision that causes cosmetic problems, pain, numbness, and discomfort $[4,5]$. Over the last two decades, several nonsurgical minimally invasive approaches for treating thyroid nodules have been developed and represent an acceptable alternative to surgery for treating symptomatic benign thyroid nodules. These techniques include percutaneous ethanol ablation, laser ablation, and radio frequency ablation (RFA) [1-3]. Percutaneous Ethanol Ablation (PEA) has been recommended as the first-line treatment option for symptomatic benign cystic or predominantly cystic thyroid nodules, and it has been shown to be more effective and safer than other techniques in previous studies [6,7]. Here, we present a case of a 44-year-old man with thyroid nodules who underwent PEA.

\section{CASE PRESENTATION}

We report the case of a 44-year-old man present with a painless mass that is getting bigger on his right neck. The physical examination confirmed the presence of a soft-elastic mass on the right side of the neck, measured $3.0 \times 3.0 \times 3.0 \mathrm{~cm}$, mobile on swallowing, no pain on palpation (Figure 1). Thyroid function tests show a euthyroid state (TSH $2.4 \mathrm{mIU} / \mathrm{L}, \mathrm{FT} 41.2 \mathrm{ng} / \mathrm{dL}$ ). The ultrasound examination in January 2020 showed a colloid cyst on the right thyroid, measured $3.03 \times 2.82$ $\times 3.56 \mathrm{~cm}$ (TIRADS 1) (Figure 2). The cytological examination showed the results of non-infectious cystic 
fluid. The patient underwent US-guided PEA using $7 \mathrm{ml}$ of ethanol by the moving-shot technique. The procedure was well tolerated by the patient and no adverse events were noted (Figure 3). A week after the procedure, there was a visible and progressive reduction of the nodule with no complaint from the patient (Figure 4).

A month after the procedure, the patient came back with no recurrences, complaints, or other complications (Figure 5).

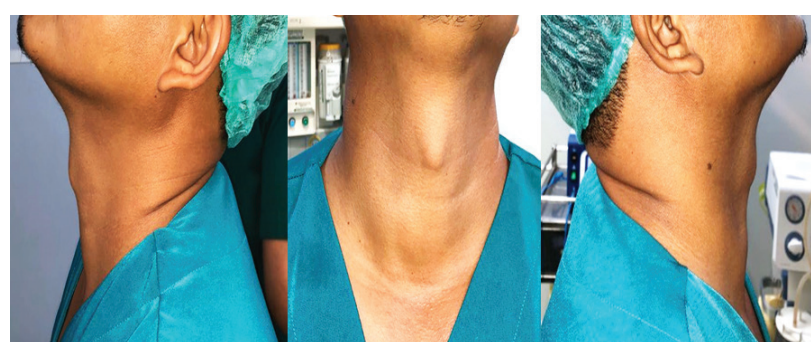

Figure 1. A 44 years old man before US-guided percutaneous EA

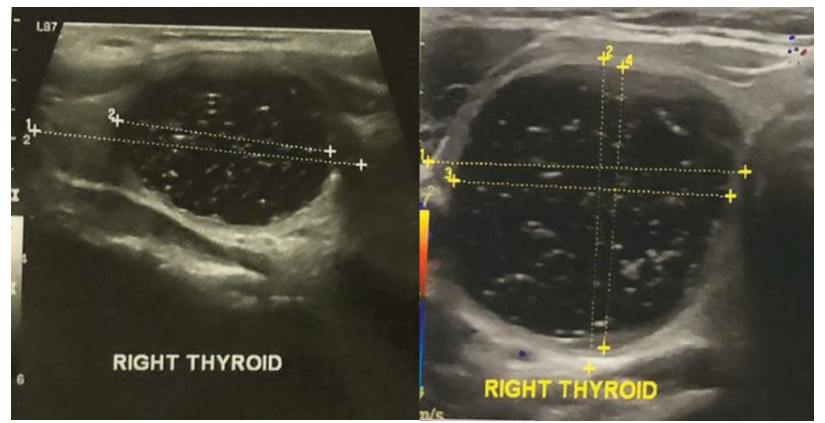

Figure 2. The ultrasound on the right thyroid there was colloid cyst
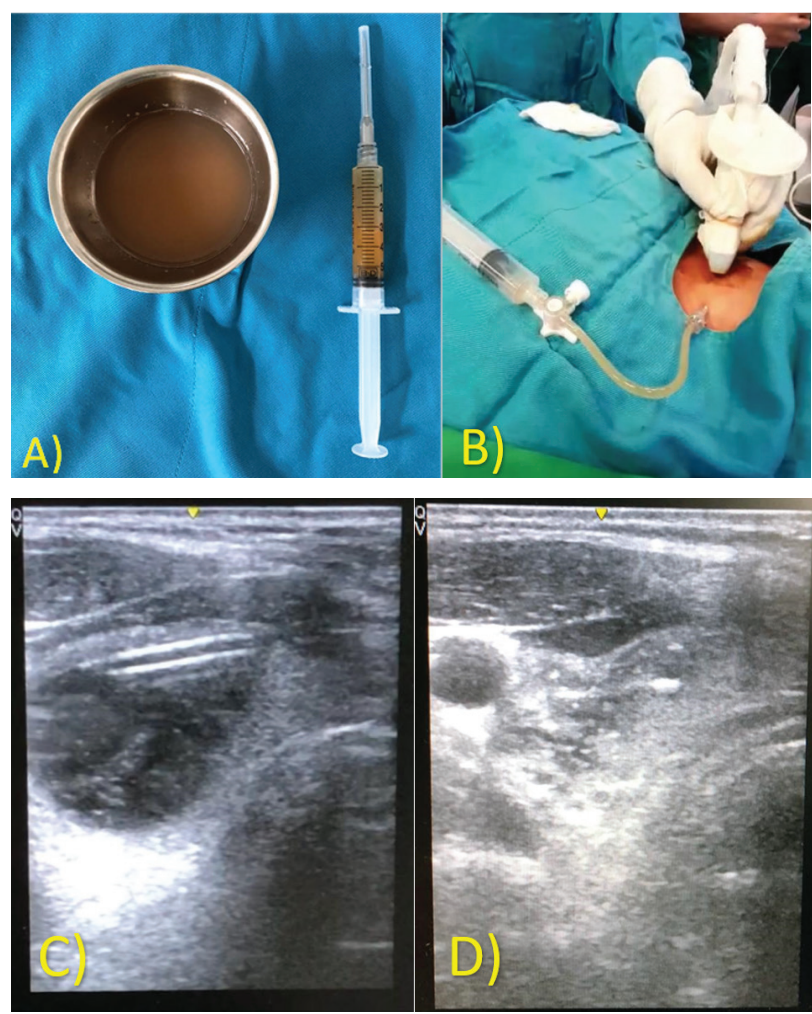

Figure 3. $7 \mathrm{ml}$ ethanol injection (A), PEA procedure (B) US guiding on PEA procedure $(C)$, US examination after PEA procedure (D)

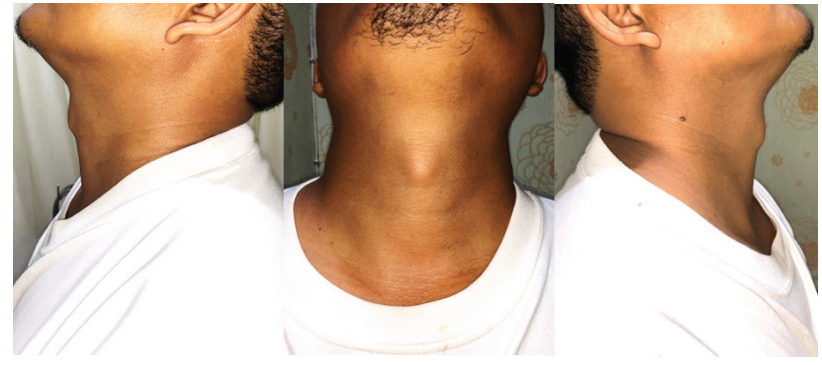

Figure 4. A 44 years old man after 1 week PEA procedure

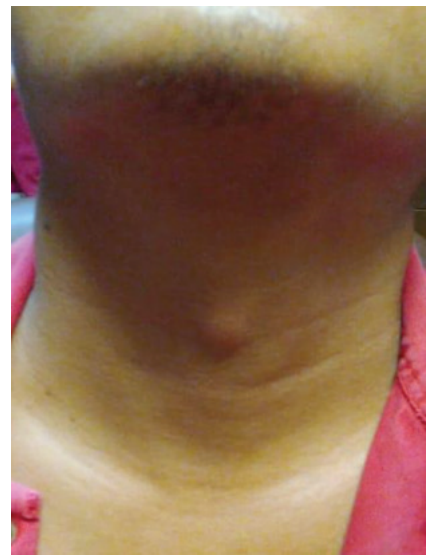

Figure 5. A 44 years old man after 1 month PEA procedure

\section{DISCUSSION}

PEA is widely used as a nonsurgical treatment usually for cystic or predominantly cystic benign thyroid nodules. The mechanisms include coagulative necrosis and ischemic necrosis. Coagulative necrosis is due to cell dehydration and protein denaturation due to diffusion. Then, ischemic necrosis is due to the formation of small blood vessel thrombus and inhibition of enzymatic activity in the tissues [8].

The indications of PEA depend on clinical conditions and patient preference. Benign thyroid nodules (cystic nodules, predominantly cystic nodules, and hyper functioning thyroid nodules) and malignant thyroid nodules (Recurrent thyroid carcinoma and primary thyroid carcinoma) are indications based on clinical conditions [8]. Patient preference is a relative indication in case of contraindication to or refusal of surgery and radioiodine therapy [9]. According to ATA, PEA is the first-line therapy for cystic nodules and predominantly cystic nodules [10].

Simple aspiration is used for diagnosis and to reduce cyst volume. The estimated cyst volume in our case was around $14 \mathrm{cc}$ with an aspiration of $90 \%$ of that volume and $7 \mathrm{ml}$ of ethanol. The volume of ethanol injected is usually as much as $50 \%$ of the volume of the aspirated liquid [11].

Reverter et al. reported PEA reduced cysts were > $70 \%$ in volume in $86.3 \%$ patients, > $80 \%$ in $61.9 \%$ patients, and $>90 \%$ in $42 \%$ patients. Comparing 
efficacy to another minimally invasive procedure for thyroid cysts, laser ablation was 68\%, RFA was 93.3\%, and PEA was $96.9 \%$. Furthermore, PEA is easier, safer, and less expensive than RFA $[5,12]$. It is estimated that around $5-25 \%$ of patients have had an EA have a recurrence. The efficacy of the EA procedure depends on the number of solid components in the nodule, the initial size of the nodule, and the amount of ethanol injected. Repetition of the EA procedure is carried out in the first to the third month of evaluation. In the fourth month, if there is still recurrence, the patient is offered a hemithyroidectomy $[11,13]$.

PEA does not need local anesthesia because there is only a transient sensation of pain with relief within minutes, completed procedure in a few minutes, and it can be performed easily on an outpatient basis [14]. The complications such as localized pain and hematoma in the puncture site, facial flushing, drunken sense, hoarseness, dyspnea, and temporary hyperthyroidism are unusual and mostly due to technical mistakes $[8,12]$. Fibrosis is a complication that can occur due to the EA procedure. Although the incidence is very minimal, fibrosis can inhibit the effects of ablation, especially in cystic predominant nodules [7].

For future directions, patient follow-up should be done monthly and an ultrasound examination annually. This is needed to look for recurrence and further complications.

\section{CONCLUSIONS}

PEA for thyroid lesions is an effective and safe method. PEA should be the first option for the treatment of pure cystic and predominantly cystic nodules. PEA is a safe procedure that is easy to repeat and to be performed on an outpatient basis.

\section{DECLARATIONS}

\section{Competing interest}

The authors declare no competing interest in this study.

\section{REFERENCES}

1. Lang BH, Wu ALH. The efficacy and safety of highintensity focused ultrasound ablation of benign thyroid nodules. Ultrasonography. 2018;37(2):89-97.

2. Basu N, Dutta D, Maisnam I, Basu S, Ghosh S, Chowdhury $\mathrm{S}$, et al. Percutaneous ethanol ablation in managing predominantly cystic thyroid nodules: An eastern India perspective. Indian J Endocrinol Metab. 2014;18(5):662-8.
3. Dobrinja C, Bernardi S, Fabris B, Eramo R, Makovac P, Bazzocchi G, et al. Surgical and Pathological Changes after Radiofrequency Ablation of Thyroid Nodules. 2015;2015.

4. Samy AK, Ridgway D, Orabi A, Suppiah A. Minimally invasive, video-assisted thyroidectomy: First experience from the United Kingdom. Ann R Coll Surg Engl. 2010;92(5):379-84.

5. Reverter JL, Alonso N, Avila M, Lucas A, Mauricio $D$, Puig-Domingo M. Evaluation of efficacy, safety, pain perception and health-related quality of life of percutaneous ethanol injection as first-line treatment in symptomatic thyroid cysts. BMC Endocr Disord. 2015;15(1):1-6.

6. Baek JH, Ha EJ, Choi YJ, Sung JY, Kim JK, Shong YK. Radiofrequency versus ethanol ablation for treating predominantly cystic thyroid nodules: A randomized clinical trial. Korean J Radiol. 2015;16(6):1332-40.

7. Park HS, Yim Y, Baek JH, Choi YJ, Shong YK, Lee JH. Ethanol ablation as a treatment strategy for benign cystic thyroid nodules: a comparison of the ethanol retention and aspiration techniques. Ultrasonography. 2019;38(2):166-71.

8. Hahn SY, Shin JH, Na DG, Ha EJ, Ahn HS, Lim HK, et al. Ethanol ablation of the thyroid nodules: 2018 consensus statement by the Korean society of thyroid radiology. Korean J Radiol. 2019;20(4):609-20.

9. Felício JS, Conceição AMS, Santos FM, Sato MMM, Bastos F de A, Braga de Souza ACC, et al. UltrasoundGuided Percutaneous Ethanol Injection Protocol to Treat Solid and Mixed Thyroid Nodules. Front Endocrinol (Lausanne). 2016;7(June):1-6.

10. Haugen BR, Alexander EK, Bible KC, Doherty GM, Mandel SJ, Nikiforov YE, et al. 2015 American Thyroid Association Management Guidelines for Adult Patients with Thyroid Nodules and Differentiated Thyroid Cancer: The American Thyroid Association Guidelines Task Force on Thyroid Nodules and Differentiated Thyroid Cancer. Thyroid. 2016;26(1):1133.

11. Kim YJ, Baek JH, Ha EJ, Lim HK, Lee JH, Sung JY, et al. Cystic versus predominantly cystic thyroid nodules: Efficacy of ethanol ablation and analysis of related factors. Eur Radiol. 2012;22(7):1573-8.

12. Papini E, Gugliemi R, Pacella CM. Laser, radiofrequency, and ethanol ablation for the management of thyroid nodules. Curr Opin Endocrinol Diabetes Obes. 2016;23(5):400-6.

13. Bennedbæk FN, Hegedüs L. Treatment of Recurrent Thyroid Cysts with Ethanol: A Randomized DoubleBlind Controlled Trial. J Clin Endocrinol Metab. 2003;88(12):5773-7.

14. Papini E, Pacella CM, Hegedus L. Diagnosis of endocrine disease: Thyroid ultrasound (US) and USassisted procedures: From the shadows into an array of applications. Eur J Endocrinol. 2014;170(4):133-46. 